\title{
カーナビゲーションにおける 位置決め技術
}

Positioning Technologies in Automobile Navigation System /

KazUo HIRANO

Key words: car navigation, GPS, beacon, map data base, map matching, fiber gyro

\section{1. は じめに}

自動車に打ける位置決め技術は, 2 つ面からの必要性 があった。

1つは，ドライバーないしは同乗者に現在位置を伝える ことにより，円滑・快適な運転の支援をすることであった. 地理不案内であるが故に運転しながらランドマークを探し た経験は，読者諸兄にも経験があるかと思われる。 た。， 行きすぎたのではないか，も5曲がらないといけないので はないか, との不安感を抱きながらの運転になっていたこ とと思われる，それらがいわゆる「カーナビゲーション (カーナビ)」の登場により解決された.

2 つには，交通管制の機能を充実することであった． 各 車両が現在位置を正確に把握し種々の通信手段により地上 システムに伝達することで, 多数配備車両の運行管理シス テム, センターシステムによる経路誘導, 公共交通車両/ 緊急車両の優先通行, 交通管制制御へのフィードバック メーデーシステム，等多くの統合システムが実現しらる. カーナビと交通情報受信装置（VICS 端末）の台数増加グ ラフを図 1 に示す.

さらに将来的には, 安全運転支援への展開が考光られて いる. 自車位置を知ることは, 地図データを持っているの で前方の道路形状を知ることと等価であり, 種々のアプリ ケーションが考光られる. すでに, 前方のカーブの曲率と 自車速度とを評価し, 必要に応じてシフトダウンする車両 がすでに量産されている.

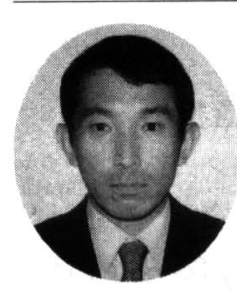

* 原稿受付 平成 11 年 6 月 17 日

** 住友電気工業(株)システムエレクトロニクス研 究開発センター (大阪市此花区島屋 1-1-3) 1974 年京都大学工学部数理工学科卒, 同年住 友電気工業(株) に入社. カーエレクトロニク ス,カーナビゲーションシステム, ITSシス テムの研究開発に従事
本文では，それらカーナビの基本技術となる自車位置の 位置決め技術について述べる.

\section{2. 自立航法技術}

1980 年代初頭に，ガスレートジャイロを搭載した本田 アコード車がいわゆるカーナビの最初である. ガスレート ジャイロは高精度であったが当時はまだ高価であり，また 地図表示もフィルム式でディジタル式ではなかった.

現在のカーナビの形式になったのは 1987 年トヨタクラ ウン車からである. 同車には, 地球の磁気を測定する地磁 気センサと車輪の回転数を測定する車輪速センサが用いら れた．地磁気センサにより絶対方位を検出する．車輪速セ ンサにより, 各車輪の回転数を得て, その差と車両のト レッドから旋回角度を検出する. 同時にその平均から移動 距離を算出する (図 2).

車両の初期位置を入力して拈けば，以後の移動方向，移 動距離を積分することにより，注ぼ現在位置が検出でき る.しかし, 積分誤差や道路構造物による地磁気の乱れ等 の要因により，時折位置修正が必要であった. この累積誤 差を吸収する方法として 1989 年にマップマッチング法が 採用された。

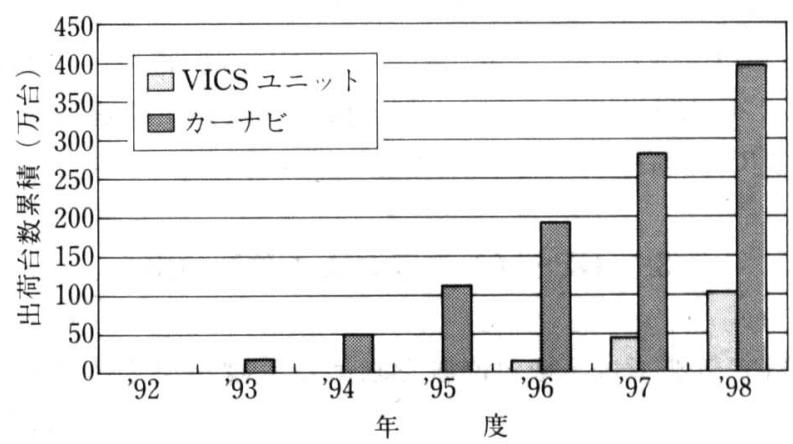

図 1 カーナビと VICS 車載機の累積台数推移 


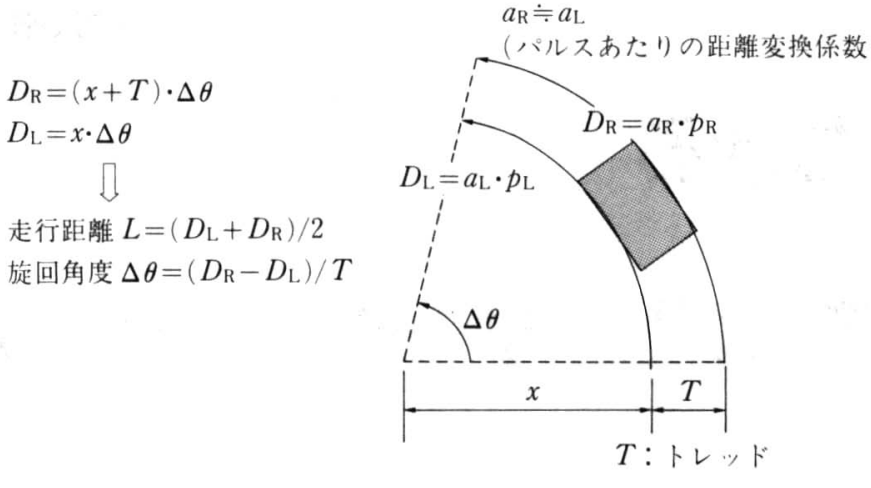

図 2 車輪速センサによる移動距離と旋回角度検出

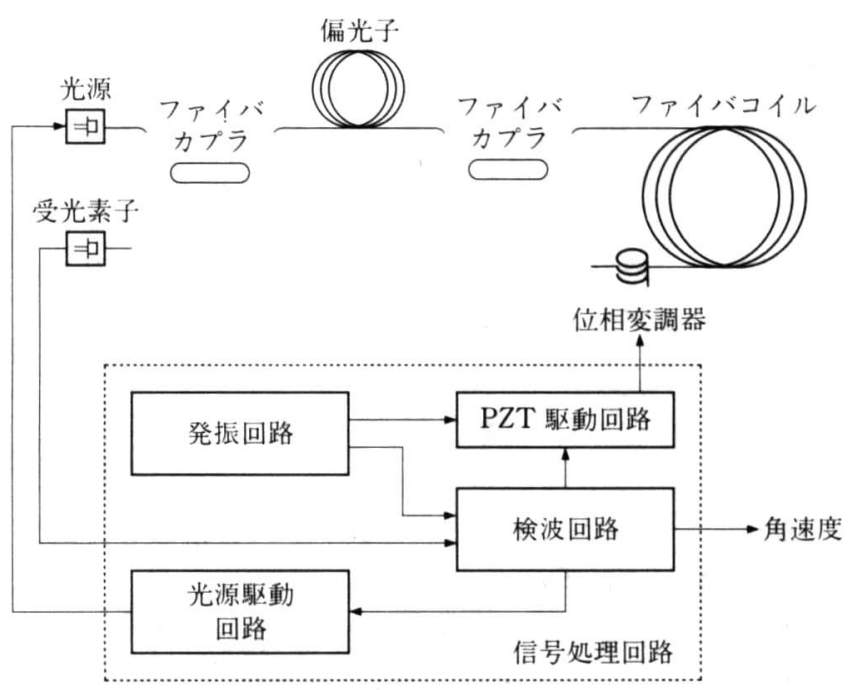

図 3 光ファイベジャイロ (FOG)（位相変調方式）

表 1 FOG の性能仕様

\begin{tabular}{l|l}
\hline オフセットドリフト & MAX $0.01^{\circ} / \mathrm{s}$ \\
スケールファクタ安全性 & $\mathrm{MAX} \pm 3 \%$ \\
ノイズレベル & $\mathrm{MAX} 0.05^{\circ} / \mathrm{s}$ \\
最大検出角速度 & $90^{\circ} / \mathrm{s}$ \\
動作温度範囲 & $-20 \sim 70^{\circ} \mathrm{C}$ \\
耐振動性 & $4.4 \mathrm{G}, 10 \sim 200 \mathrm{~Hz}$ \\
耐湿性 & $90 \% \mathrm{RH}\left(65^{\circ} \mathrm{C}\right)$ \\
\hline
\end{tabular}

1991 年の日産セドリック車では, 旋回角度のセンサと して光ファイパジャイロ（図 3）が用いられた.

それ以前の航空機用のものに，測定可能範囲等仕様に見 直しがかけられ大幅にコストダウンが図られた（表 1).

これにより位置検出精度が飛躍的に高まった。

自立航法のセンサとしては, より安価な振動ジャイロが 1992 年に採用され, その小型安価な特徵を元に幅広く現 在まで採用されている(図4).

\section{GPS インフラによる位置検出}

自立航法では，絶対位置を求める手段がなく，マップ マッチング手法で累積誤差をリセットしても完全ではな い. 位置修正操作の頻度は大幅に減少されたが，時には必

\section{動作原理}

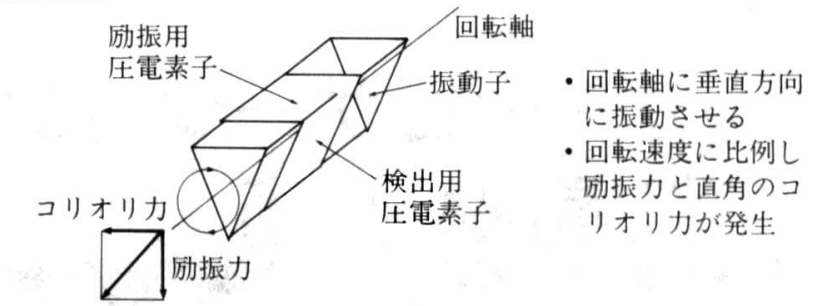

特 徵

・低消費電力

- 小型

- 短起動時間

・低コスト

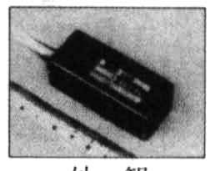

外 観

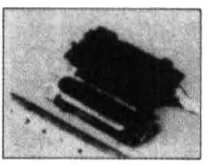

内 部

図 4 振動ジャイロ

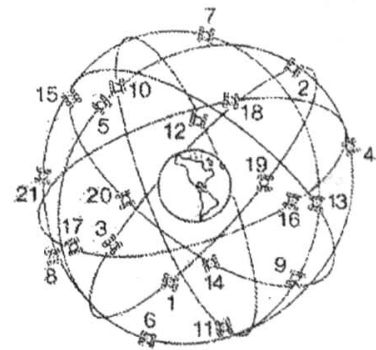

衛星の配置

・システムの運用者

・正式運用開始

・システム構成

・衛星周期

- 位置検出精度

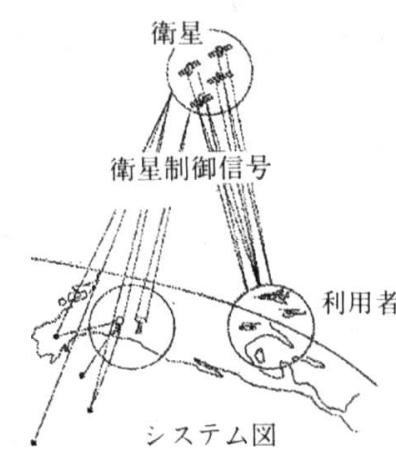

米国

1993 年 1 月 約 12 時間

$\sim 100 \mathrm{~m}(\mathrm{C} / \mathrm{A}$ コード・商用 $)$
24 個の衛星，地上局利用者受信機

図 5 GPS (Global Positioning System)

要であった. 地理不案内なところで現在位置を正しく入力 するのは矛盾を含んだ操作であった。

1990 年代に入って，米国が軍事目的に整備してきた GPS (Global Positioning Satellite) 衛星の数が整ってき て使用可能時間が増えてきた。これにあわせてカーナビに おいても，GPS 受信機を搭載したものが登場した，GPS 受信機では, 複数の衛星からの電波の到達時間差をると に, 自車位置の地球上の座標 $(x, y, z)$ と車載受信機の時 計の時刻ずれ $\Delta t$ が求められる（図 5)。元々軍事目的の衛 星であり意図的に織り込まれた誤差のため，その精度は $100 \mathrm{~m}$ 程度であった. しかし GPS 受信機の車両への取付 けは比較的容易なととから，アフターマーケット対応ナビ が普及する要因となった，その初期のものは，GPSによ る位置検出だけのものが主流であった．衛星の整備はその 後も進み 1994 年には 24 時間連続の測定が可能となってい る.

\section{4. マップマッチングによる位置検出}

自立航法ではセンサによる誤差が累積する.また GPS 衛星による位置決めでは GPS 衛星からの電波が受信でき 


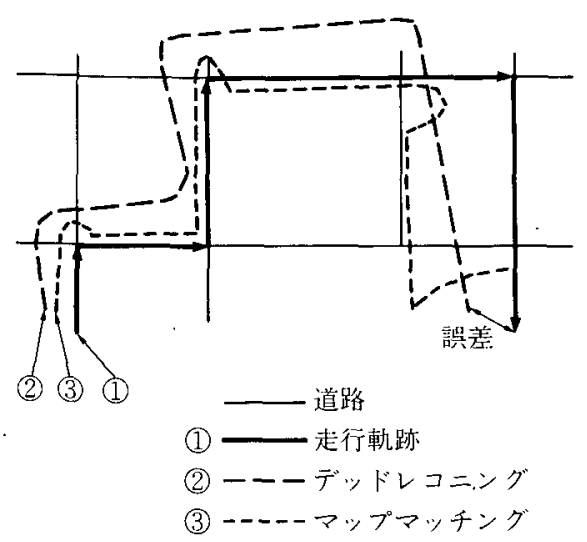

図 6 地図マッチング方式
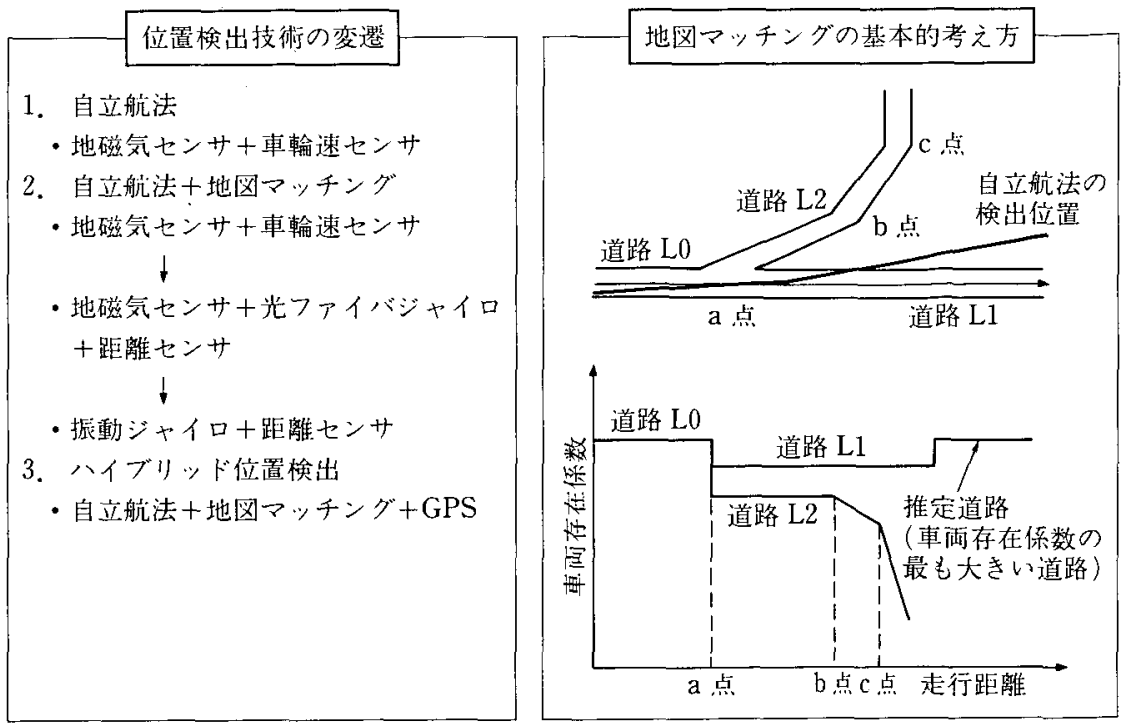

図 7 位置検出方式の変遷と地図マッチング

ないトンネルなどで機能が発揮できない：それらを補う技 術としてマップマッチング技術が開発された，これは，車 載機が保有する道路ネットワーク情報とセンサや GPS に よる位置測定結果を照合することにより，自車位置を的確 に道路上に補正する技術である（図 $6,7,8$ ).

自動車は地図データに登録されている道路上以外にも， 駐車場内や構内道路，新規開通道路を走行することが通常 であり，必ずしも道路上に設定することが正解ではない． そのあたりは各社にて工夫され現在では各社なりに相応の 位置検出精度を実現している。

\section{5. 精度の要, 地図データベース}

マップマッチングロジックが位置検出精度の決め手であ るが，その精度は地図データベースの精度に大さく依存し ている.いくらロジックが完譬でる対象道路が地図データ ベースに登録されていなければ位置検出精度に影響が及ん

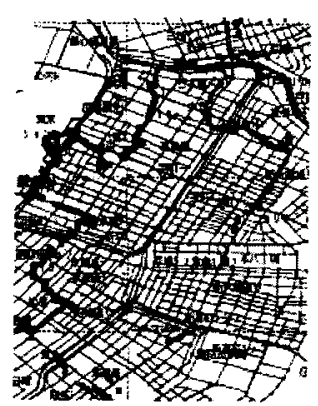

GPSのみ

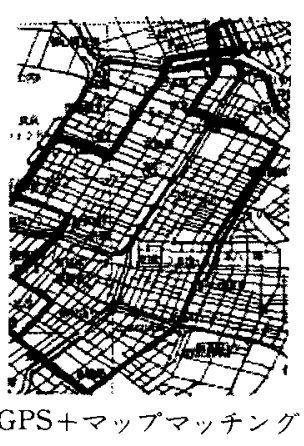

図 8 位置検出方式に上る走行軌跡比較
でしまう，そのため，高精度な地図ネットワークデータが カーナビに括ける位置検出性能の真の必要条件であると 言っても過言ではない，地図ネットワークはリンク（道 路）とノード（交美点）からなって颃り，てれらに対応さ せて全国の表示から街区図表示用の詳細表示地図データが 整備されている(図 9)。このネットワークの良さ之表示 の見栄觉の良さといら両条件を備古ることがカーナビに拉

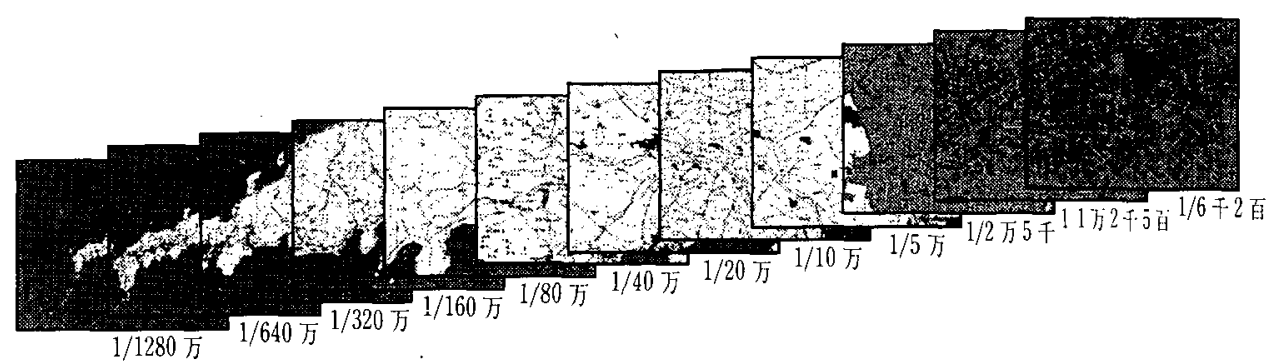

（1）一貫性の要求

\begin{tabular}{|l|l|l|}
\hline 1 & 地 域 & 夾標系 \\
\hline 2 & 縮 尺 & $\begin{array}{l}\text { ノード座標/番号 } \\
\text { リンク番号 }\end{array}$ \\
\hline 3 & 使用目的 & $\begin{array}{l}\text { 位置, 経路, 表示, } \\
\text { 公送, 管理 }\end{array}$ \\
\hline
\end{tabular}

（2）整備上の制的と対応策

\begin{tabular}{|l|l|l|}
\hline 1 & 粗 $\rightarrow$ 詳細化 & ノード座標合わせ \\
\hline 2 & 部分 $\rightarrow$ 全体 & はめ込み \\
\hline 3 & 小機能 $\rightarrow$ 多機能 & 桩張性 \\
\hline 4 & 小更新 $\rightarrow$ 多更新 & 部分修正 \\
\hline
\end{tabular}

図 9 地図データべース 


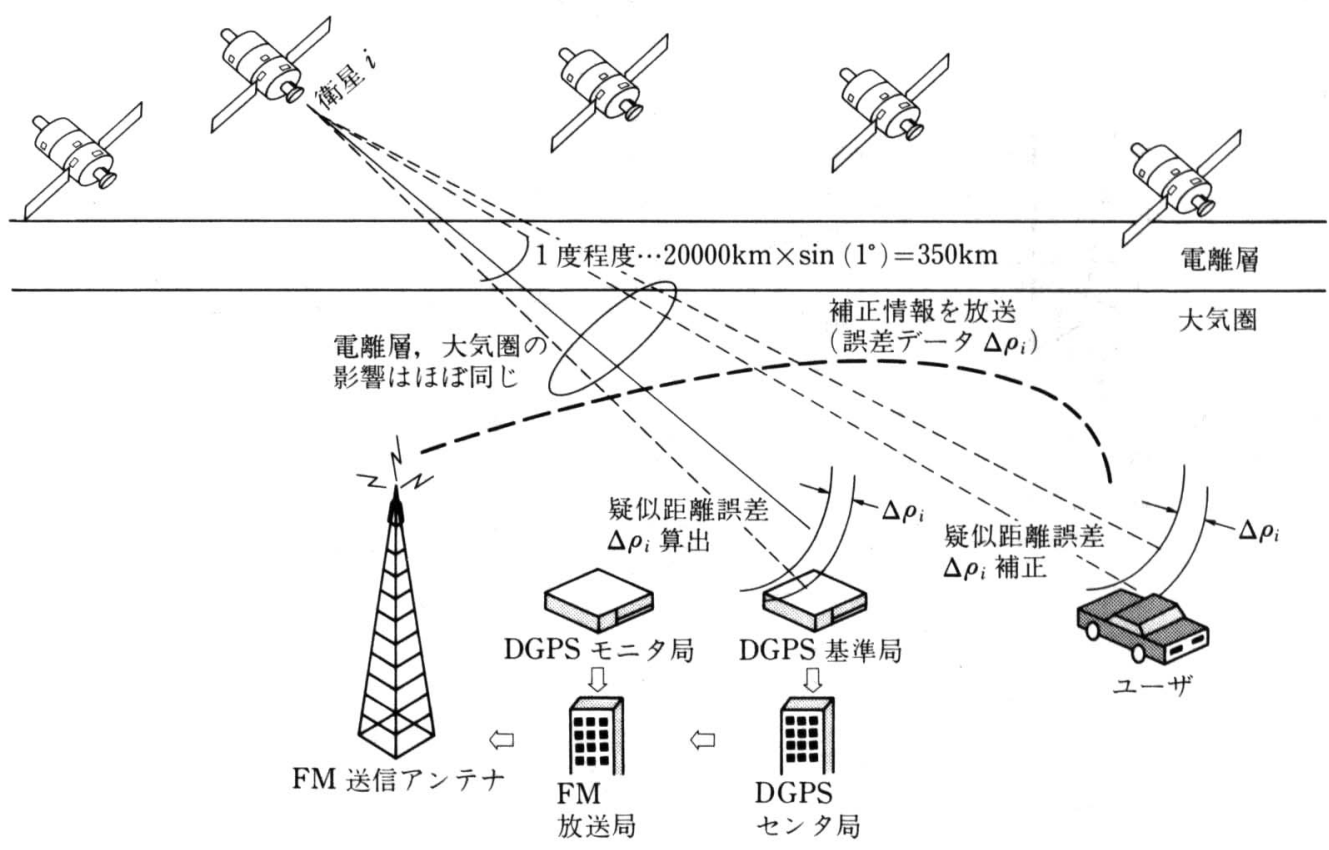

図 10 DGPS 原理図

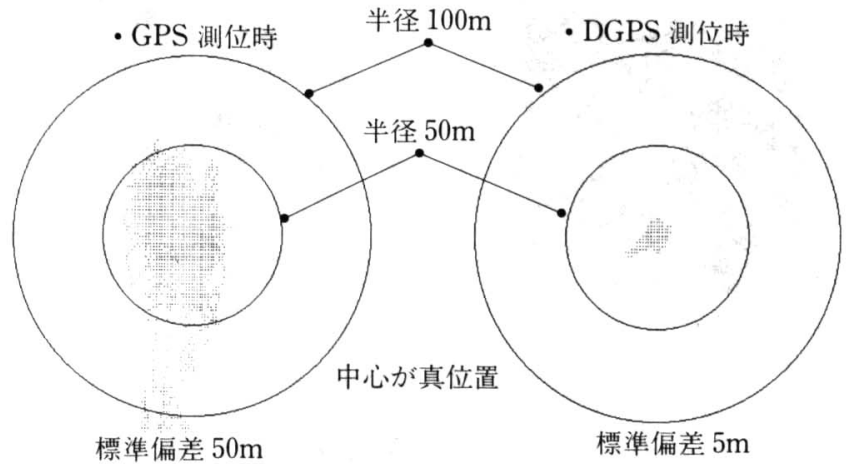

図 11 位置検出誤差の比較（GPS vs. DGPS）

いては必要条件となっている.

\section{6. さらなる位置検出精度向上の手段}

\section{1 DGPS}

3 章でGPSによる位置検出精度には意図的に織り込交 れた誤差が入ることを述べた。 この誤差要因を検出しそれ を補正することで精度を上け゚るのが DGPS (Differential GPS）である.

これは基準点と呼ばれる位置が既知の地点において GPS 位置測定を行い, 既知の位置と測定結果の照合を行 い, その詋差要因を FM 多重等の通信手段でカーナビに 伝達する. カーナビでは受信した誤差要因情報を活用して 精度良く位置検出を行らものである（図 10 ).

これにより GPS 受信時の誤差は $10 \mathrm{~m}$ 程度と従来の $1 /$ 10 程度に提言された（図 11）.

\section{2 ビーコン}

道路上に設置された電波ビーコンや光ビーコンからは交

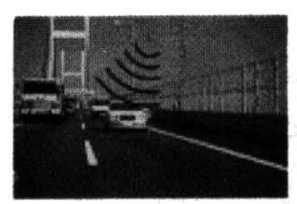

電波ビーコン

(高速道路)

電波を媒体として, ピーコンが設置された 場所に必要な道路交通 情報を提供する

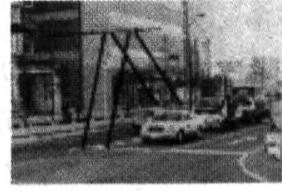

光ビーュン (主要幹線道路) 光を媒体として,ビー コンが設置された場所 に必要な道路交通情報 を提供する

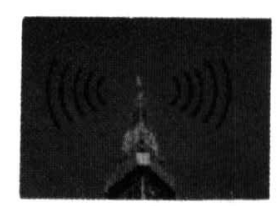

FM 多重放送 (既設放送設備) FM 放送波を利用儿 て，広いェリアに道 路交通情報を提供す る
図 12 道路交通情報の提供 3 メディア

通情報（VICS 情報）と共に，ビーコン設置位置座標も送 信されている.ビーコンの受信範囲はごく狭域であるた め, ビーコン情報を受信した車両にとってはその精密な位 置情報をもとに位置決めすることが可能であり, VICS 情 報に対応している車載機の相当数がこのビーコン位置情報 を活用している. 光ビーコンの通信は車線単位であるた め, 車線の位置決める可能となっている（図 12）。

\section{7. カーナビにおける位置決め技術の今後の展開}

以上述べたように, カーナビに打ける位置決め技術は, センサ技術の進展, GPS, ビーコン等インフラの整備進 展, 高度なマップマッチングロジックを高速で実現できる 半導体技術の進展, 高精度かつ大容量の地図データを格納 できるCDROM，DVDROM 等の記憶媒体技術の進展， に支光られ進歩してきた（図 13,14). 同時にカーナビも 当初の $1 / 25000$ 地図上への現在位置表示機能から, 街区 図表示上への現在位置表示や, 的確な右左折指示へと要求 機能が拡大してきた。これらはますます高精度の位置決め 


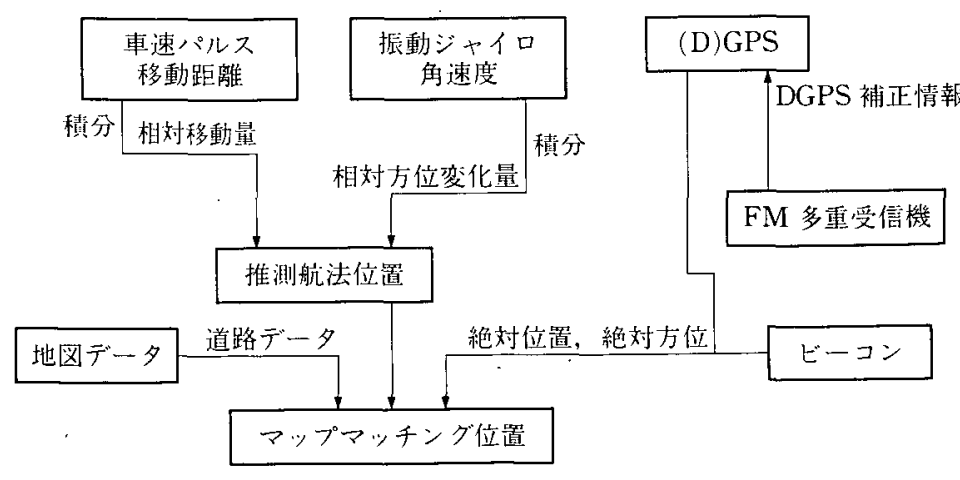

図 13 位置検出ソフトにかかわるセンサ構成

\section{1. 高精度位置検出}

(1) 安価・高精度・小型のセンサ

(2) PPM 万式マップマッチング

(3) ハイブリッド位置検出方式 積分位置と絶対位置

2. 詳細地図データベース

・1/2 500 都市計画図から

の入力

・ディジタイズカーによ る道路計測

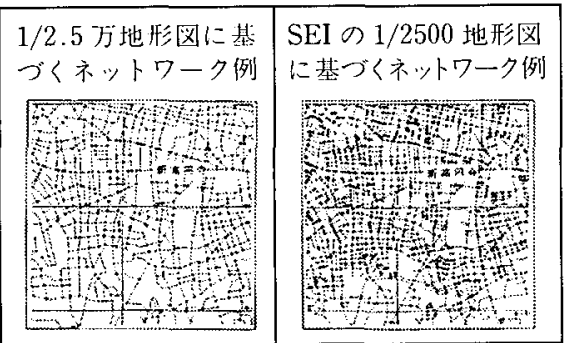

図14 カーナビダーションに括ける位置決め技術

技術を要求している.

5 省庁（建設省，警察宁，通商産業省，運輸省，郵政 省）がとりまとめたITS 構想には多くのサービス分野で のシステム構想が盛られているがそのほとんどすべてが車 載機による高精度の位置決め技術を前提としている. 前後 の車両と区別できる位置決め精度の実現, 車線単位の横方 向弁別ができる位置決め精度の実現をめざして, 今後とも
位置決め精度の向上に向けた研究開発が進められて いる.

\section{参 考 文 献}

1）三藤邦彦：カーナビゲーションシステム, IATSS Rev., 17, 2, (1991).

2）田上ほか：自動車用慣性航法装置エレクトロ・ジャ1 ロケータ，自動車技術，36，5（1982）。

3）土居陽一, 吉井正明, 厚朴靖広, 天目健二, 清水 修，井上弥，長尾真伸，内田正樹：自動車の位置検 出方式の開発，住友電気，137，(1990)。

4）平野和夫，松崎伸一，土居陽一，吉井正明：ナビゲー ションシステムに持けるセンサ技術，センシング技術 応用研究会第 75 回研究例会, (1990).

5) R. French : Map Matching Origins, Approaches and Applications, 2nd Int. Symp. Land Vehicle Naviga. tion, Munster, Germany, (1989).

6）三藤邦彦，天目健二，土居陽一，清水 修：自動車の 自立航法装置の開発, 電子情報通信学会SANE 8747, (1987).

7) S. Honey, W. Zavoli, K. Milnes, A. Phillips, M White and G. Loughmiller : Vehicle Navigational System and Method, U. S. Patent No. 4, 796, 191, 1989.

8）緒方ほか：衛星航法 NAVSTAR/GPSとその利用， 漁船， 273 (1988).

9）矢野治人，徳永利道，平佐美明：ューノスコスモカー コミュニケーションシステムの紹介，マツダ技術，8 (1990).

10）小林祥延, 藤田安臣, 平野和夫, 松田自弘, 出川裕 之, 川村静治, 小田垣秀雄, 福永邦彦：ナビゲーショ ン用緿合情報制御ソフトウェ $\boldsymbol{~}$, 住友電気, 136 (1990).

11) N. Yumoto: Status of Advanced Driver Information Systems in Japan, 70th Ann. Meeting, TRB, Washington D. C., (1991).

12) P. Belcher and I. Catling : Electronic Route Guidance by AUTOGUIDE: the London Demonstration, Traffic Engineering + Control, (1987)

13）松崎伸一, 小林祥延, 中野啓之, 駕見公一, 西田 太, 能本 博文, 礒山芳一, 香川浩司, 横手 悟, 服部 理, 反田幸男, 西 康彦，三村竜二，羽山登敏：カーナビダーションシステ ム Cruise Mate (TM) SNV-AD 10, 住友電気, 148 (1996)。

14）日本測地学会：GPS一人工衛星に上る精密測位システム，日 本測量協会, (1989) 